\title{
A Nonpermanent Seat in the United Nations Security Council
}

\section{Why Bother?}

\author{
Ann-Marie Ekengren \\ Department of Political Science, University of Gothenburg, Sweden \\ Ann-Marie.Ekengren@pol.gu.se
}

\author{
Fredrik D. Hjorthen \\ Department of Political Science, University of Oslo, Norway \\ f.d.hjorthen@stv.uio.no
}

\author{
Ulrika Möller \\ Department of Political Science, University of Gothenburg, Sweden \\ Ulrika.Moller@pol.gu.se
}

\begin{abstract}
This article contributes with a novel systematic theoretical and empirical exploration of why states find a nonpermanent seat in the UN Security Council attractive. Three conceptualizations of power-to influence, to network, and to gain status-guide the empirical analysis. A telephone interview survey with diplomatic staff at Member States' permanent missions to the United Nations in New York provides readers with original and unique empirical knowledge of state perceptions of power. The candidature for a seat comes with expectations of influencing decision-making, despite modest estimations of the opportunity to have impact. Opportunities to network and to gain status are not frequent reasons for a candidature. Diplomats' estimations are nevertheless higher on the opportunity to actually establish relevant relationships and to gain status brought by a seat.
\end{abstract}

\section{Keywords}

Security Council - nonpermanent members - elections

(C) ANN-MARIE EKENGREN, FREDRIK D. HJORTHEN AND ULRIKA MÖLLER, 2020 | DOI:10.1163/19426720-02601007

This is an open access article distributed under the terms of the CC-BY 4.8License. Brill, com04/26/2023 12:13:51AM 
Why do states seek a nonpermanent seat in the UN Security Council? The UN Charter gives the Council substantial political power, specifically stating that the UN Members "confer on the Security Council primary responsibility for the maintenance of international peace and security, and agree that in carrying out its duties under this responsibility the Security Council acts on their behalf." ${ }^{\prime}$ Despite their formal power, there are important limitations to the influence Council members are able to wield. For one, the capacity of the Council to exercise its authority is highly contingent on the voluntary cooperation of states, which in turn depends on the perceived legitimacy of the Council. ${ }^{2}$ Moreover, a number of circumstances contribute to monopolizing effective decision-making power with the Permanent Five ( $\left.\mathrm{P}_{5}\right)$, reducing the role of the Elected Ten (E1O) to considering "previously cooked decisions." ${ }^{3}$ In addition to the veto, the $\mathrm{P}_{5}$ has access to the institutional memory of the Council, has more experienced diplomatic staff, and has competence in practices such as "penholding." Yet this does not appear to have curbed the enthusiasm of other UN members for seeking an elected seat. Instead, there has been an increase in competition, leading to more intensive and elaborate election campaigns. ${ }^{5}$ The competitive challenge facing aspiring members is compounded by the increase in UN membership, from 104 in 1963 to 193 in 2018. Member States seeking an elected seat are now up against more competitors

1 UN Charter, Article 24.

2 As described by Hurd 2008a: 12, "Its peculiar combination of extensive powers and political limitations means that its effectiveness depends on its legitimation." See also Hurd 2008b, 2008c.

3 Keating 2016.

4 Luck 2006; Ralph and Gifkins 2016.

5 The current order relies on a reform in 1963 through which the number of nonpermanent seats was extended from six to ten. Rotation of five seats at the time for the coming two years takes place through annual election. The selection of candidates takes place on a regional basis within five groups. The nomination process varies between the regional groups in their practice to apply "clean slates" (the endorsement of one candidate per seat) or contested elections (the endorsement of several candidates in competition over seats). The regional representation is set to three from Africa, two from Asia and the Pacific, one from Eastern Europe, two from Latin American and the Caribbean, and two from Western Europe and others (including Canada, Australia, and New Zealand). On even calendar years, the elections are on one seat from the African group, one from the Asia Pacific group, one from the Latin America and Caribbean group, and two from the Western European and Others group. On odd calendar years, the elections are on two seats from the African group, one from the Asia Pacific group, one from the Latin America and Caribbean group, and one from the Eastern European group. 
and need to win the support of more countries to secure the required number of votes. ${ }^{6}$ Accordingly, securing a nonpermanent seat has been described as "more of a prize than ever." It might seem, therefore, that the gains of an elected seat outweigh the costs of competing for it. But what exactly do aspiring members hope to achieve? Departing from the overarching assumption that power and influence is at stake, in this article we investigate what states think they will achieve by serving on the Council. We build on new data gathered from a telephone interview survey with diplomatic representatives in New York.

The article is structured as follows. First, we present existing research on states' aspirations to be elected to the Security Council, situate our own contribution in relation to previous research, and bring forward relevant theoretical and empirical lessons. We then develop our own theoretical framework, building in part on the results of the inductive approaches found in earlier case studies. In light of previous research, we argue that it is constructive to consider states' aspirations for an elected seat as an expression of a strive for power and influence. This leads us to a theoretical framework that identifies three types of power-enhancing benefits that states seek through Council membership: (1) influencing the agenda; ${ }^{8}(2)$ networking and social interaction; and (3) elevating (or maintaining) status. We do not evaluate the extent to which membership actually brings these benefits about; different states have different abilities to achieve these advantages. Instead, we are interested in whether aspirations for membership come with these expectations. Once the theoretical framework is in place, we present how the empirical investigation was conducted. The theoretical framework was operationalized into questions posed to states' permanent representations in New York through a telephone interview survey. Our main findings are presented in the empirical section. A final section concludes.

6 A two-thirds majority in the UN General Assembly is required for election.

7 Malone 2000, 23.

8 It is worth noting that "agenda" may be understood in different ways, and that on some understandings there may be little scope for influence even for powerful states. See, for example, Sievers and Daws 2014, Ch. 2. Here, we understand "influencing the agenda" as being about influencing Security Council decision-making. 


\section{States' Aspirations for an Elected Seat in the Security Council}

Surprisingly, the existing literature provides few answers as to why states campaign for a nonpermanent seat in the Security Council. ${ }^{9}$ There are, however, a few previous studies of relevance. These have as their focus to: (1) identify factors that determine success in the elections; ${ }^{10}(2)$ describe and assess the campaigns in particular elections; ${ }^{11}$ or (3) describe and assess the candidature and term of a particular state. ${ }^{2}$

Beginning with the most recent quantitative study, Axel Dreher et al. focus on explanatory factors such as the peace norm, the role of foreign aid, the relationship to powerful states, cultural traits, and the norm of turn-taking, during the period from 1970 to 2005 . The results of the study support: (1) the peace norm; (2) the turn-taking norm; and (3) population size. ${ }^{13}$ To specify, the presence of a peace norm rests on the UN's main mission being to prevent conflict and to promote peace; Member States are therefore encouraged to take the peace credentials of Security Council candidates into consideration when voting. Hence, members engaged in civil war are less likely to become members of the Council. The turn-taking norm reflects the practice of a set order for candidatures within certain regional groups. Moreover, the study suggests that, for candidates in competitive races, it might be easier to gather support for firsttime candidates, and for candidates that have had longer spells outside the Council. According to Dreher et al., population size reveals a pattern whereby populous countries are elected more frequently. By contrast, results on culture traits and foreign aid are mixed which, as we show below, is an interesting finding compared with results from some earlier studies, as it suggests a change of explanatory factors for success over time.

The remaining quantitative studies on the topic date back to the Cold War. Marshall R. Singer and Barton Sensenig studied the election of states to the

Literature on Security Council reform is vast. Having familiarized ourselves with parts of that literature, we conclude that some of the reasons for reform correspond with the reasons for seeking a seat in the Council: increased status, influence over agenda and decision-making, and being perceived as a second-rank power. The reasons for reform also include efforts to enhance efficiency, transparency, and multilateralism as well as regional representation, among other things. The literature on Security Council reform confirms that the reasons related to influence are important drivers for state action. See, for example, Thakur 2004; Drieskens 2015.

$10 \quad$ Singer and Sensenig 1963; Weigert and Riggs 1969; Dreher et al. 2014.

11 Malone 2000.

12 Langmore and Farrall 2016.

13 Dreher et al. 2014. 
most important UN offices, identified as the nonpermanent Security Council membership, General Assembly presidency, and First Committee chairmanship, during the period 1946-1962. The study addressed power as: (1) material capabilities measured through gross national product (GNP); (2) closeness with a "super ally," measured through similarities of voting in the UN; and (3) received aid..$^{14}$ The results showed that states with close political and economic ties with the United States were overrepresented in the Council, especially up until the early 195 os..$^{15}$ Building on Singer and Sensenig, Kathleen Maas Weigert and Robert E. Riggs studied the distribution of UN offices in a single geographical region, Africa, during $1961-1965 .{ }^{16}$ The study addressed the importance of: (1) economic and military capabilities; (2) economic and social development; and (3) broader participation in UN affairs. ${ }^{17}$ The results point to the significance of the third explanation. The results by Weigert and Riggs also point to the relevance of being perceived as a "good" UN participant to the prospects of winning a seat. ${ }^{18}$

Comparing the more recent results from Dreher et al. with the studies conducted during the Cold War suggests that closeness to a powerful state and the role of aid are factors of potentially declining relevance. ${ }^{19}$ Arguably, the effects of overall engagement within the $\mathrm{UN}$ and whether a candidate is perceived as a "UN ally" also would be worth investigating for the period after the Cold War. The latter contains a potential motivation for seeking office since the relevance of the Security Council should be greater for states with a stronger dedication to multilateralism. Finally, the more recent results from Dreher et al. are interesting since they indicate that UN norm compliance might have become more important over time.

\footnotetext{
14 Singer and Sensenig 1963, 902.

15 Given the Cold War bipolarity, it is surprising that the Soviet bloc was so consistently out of favor when it comes to the important offices in the UN.

16 Gregg 1965.

17 Economic and military capabilities are measured as gross national product, UN contributions, size of armed forces, total number of physicians, college and university enrollment, population, and US aid; economic and social development measured as newspapers, radios, gross national product, armed forces, physicians, college and university enrollment, and primary and secondary school pupils per capita; broader participation in UN affairs measured as size of permanent UN mission, length of speeches, resolutions and amendments sponsored, and number of UN Secretariat staff.

18 Weigert and Riggs 1969, 16.

19 There are studies focusing on the effects of being elected to the Security Council. Bueno de Mesquita and Smith 2010 show that countries elected to the Security Council receive more aid during their time in the Council and underperform in terms of democratic record in relation to similar countries not elected. See also Kuziemko and Werker 2006.
} 
In addition to these quantitative studies on determinants for success, there are some relevant case studies. In a study of Canada's candidature for the 19992000 term, David Malone points to increasing competition for the elected seats, especially in the Western European and Other Group (WEOG). While Malone did not study why states might want a nonpermanent seat in the first place, the reasons identified include "to underscore international prestige," "to advance a national position in a dispute," and to pursue "broader objectives." 20 In another single-case study, John Langmore and Jeremy Farrall examined Australia's experience in the Security Council during 2013-2014. Within the context of studying how successful a nonpermanent member can be in achieving their goals, given the presence of the $\mathrm{P}_{5}$, they touched on the question of why states choose to campaign. According to Langmore and Farrall, Australia's reasons for pursuing the campaign were that: (1) the Council in itself had become more important; (2) Australia had certain security interests in Afghanistan; (3) Australia had important assets; (4) it was Australia's turn; and (5) Australia needed to pursue certain ideas and values. ${ }^{21}$ They further conclude that the campaign could be seen as a way of "strengthening Australia's and, therefore [Foreign Minister Kevin Rudd's] own international influence."22

While the results of Malone and Langmore and Farrall are sensitive to any particularities of the cases under scrutiny, they are nevertheless instructive to our aim of presenting a more systematic empirical examination of why states seek a nonpermanent seat. The objectives identified by Langmore and Farrall are somewhat more specific than those identified by Malone, but they both circle on different aspects of influence and power such as influence over Security Council decision-making and using a seat to gain prestige. Furthermore, while candidates might have a narrower-more self-interestedsecurity agenda, the studies indicate that we should not rule out the possibility of a broader, value-laden agenda. Canada's objective to put human security on the UN agenda attests to the presence of such ambitions. ${ }^{23}$

Previous studies addressing beliefs and expectations in relation to campaigns have rarely considered who represents these ideas on behalf of the state. We depart from the view that the state is a corporate agent, which implies regularities among those who represent and act on its behalf. ${ }^{24}$ Typical state agents in the field of international relations are prime ministers, foreign ministers,

\footnotetext{
20 Malone 2000, 6-7.

21 Langmore and Farrall 2016, 6o-61.

22 Langmore and Farrall 2016, 61.

23 Malone 200o, 7.

24 Pettit 2001; Wendt 2004.
} 
and diplomats. While politicians are the final decision-makers, diplomats provide political advice based on their interactions as representatives of the state. While politicians enter and exit offices of power on a regular basis, diplomats often "personify" the state for longer periods of time, albeit through different missions and assignments. For this reason, we chose to focus on the diplomatic category; specifically, the permanent missions in New York since the UN headquarters is the most important site for campaign activities. The permanent representative of a state aiming for a seat on the Security Council needs to meet with as many other permanent representatives as possible, hoping that this will translate into votes. Arguably, diplomats at the permanent missions are experts on what their state hopes to gain from a seat.

Power-Enhancing Benefits from an Elected Seat: Toward a Theoretical Framework

Our investigation touches on the view of international politics as an ongoing quest for power. While it might be uncontroversial to argue that membership of the Security Council brings opportunities to power, we need to spell out the details. To do so in a structured manner, we take into consideration a theoretical development whereby the conceptualization of power has moved somewhat away from power as a property that mainly rests on a material base toward power as shaped by and through social relations. The material understanding was dominant largely due to the prominence of structural realism, whereas constructivism has paved the way for the more social view. ${ }^{25}$ Against this background, we suggest structuring the relevant benefits from representation in the Council along a dimension that runs from chiefly material toward more social with regard to the understanding of power. To illustrate: Reasons of national security would belong at the one end, and the ambition to elevate one's status through reputation as a Council member at the other. Below, we specify these possible power-enhancing benefits from a Council seat by revisiting relevant parts of the main international relations theories.

The notion of "hard power," or "the ability to get others to do what they would otherwise not do through threats or rewards," captures the realist understanding of power. ${ }^{26}$ Structural realism proposes that state power is determined through material, mostly military, capabilities. It expects great and ris-

25 Barnett and Duvall 2005, 42.

$26 \quad$ Keohane and Nye 1998. 
ing powers to focus on "relative gains" (or losses) to maintain (or improve) power in relation to each other. For small states with limited material ability to engage in balancing, the best road to security is instead to bandwagon with a great power. ${ }^{27}$ Translated into the candidature for an elected seat, we may expect states to consider a term in the Security Council attractive for reasons of security. Stronger states might have expectations of influencing the decisionmaking in this regard by the help of their capabilities. Weaker states might seek the opportunity to exercise influence on the agenda by establishing closer relationships with the powerful $\mathrm{P}_{5}$.

The notion of "soft power," or "the ability to get what you want through attraction rather than coercion or payments" captures how the neoliberal view of power and influence pays more attention to symbolic and ideational components. ${ }^{28}$ The neoliberal perspective, too, considers the material base of power but emphasizes economic rather than military assets. Furthermore, it acknowledges that states not directly involved in great-power competition might strive to strengthen the multilateral order for the sake of principle as well as for the benefit of their long-term security. Translated into the candidature for an elected seat, we may expect states to consider a term in the Security Council to be relevant as an opportunity to influence the agenda on topics related to the multilateral order, and for the sake of establishing stronger networks. The pattern of economic benefits for developing countries, through an increase in aid following a term in the Council, suggests that nonpermanent membership indeed comes with the opportunity to improve relations with the $\mathrm{P}_{5}{ }^{29}$

The constructivist contribution to the social understanding of power has relied on attention to international norms. The influence of norms can operate through their capacity to transform state interest by means of identity transformation through pressures of socialization. ${ }^{30}$ Analytical attention paid to the issue of identity has also spurred renewed interest in the role of social recognition, ${ }^{31}$ and the quest for status in international politics. ${ }^{32}$ While recognition relates to power in the sense that it grants agency, ${ }^{33}$ status also positions states

\footnotetext{
27 Waltz 2010; Mearsheimer 2001.

28 Nye 2004.

29 Bueno de Mesquita and Smith 2010; Dreher, Sturm, and Vreeland 2006, 20o9; Vreeland and Dreher 2014.

$30 \quad$ Finnemore 1996; Finnemore and Sikkink 1998.

31 Bartelson 2013; Lebow 2008; Ringmar 1996, 2002; Wolf 2011.

32 Paul, Larson, and Wohlforth 2014; De Carvalho and Neumann 2015.

33 Honneth 1995.
} 
TABLE 1 Power-enhancing benefits brought by an elected seat in the Security Council: influence the agenda, establish networks, and status

\begin{tabular}{|c|c|c|}
\hline $\begin{array}{l}\text { A nonpermanent seat brings } \\
\text { influence over the agenda }\end{array}$ & $\begin{array}{l}\text { A nonpermanent seat } \\
\text { brings improved networks }\end{array}$ & $\begin{array}{l}\text { A nonpermanent seat } \\
\text { brings status }\end{array}$ \\
\hline Guard one's national security. & Access to the Permanent 5. & Seek elevated status. \\
\hline $\begin{array}{l}\text { Promote specific principles and } \\
\text { values. }\end{array}$ & $\begin{array}{l}\text { Establish other types of con- } \\
\text { tacts. }\end{array}$ & $\begin{array}{l}\text { Maintain the status one } \\
\text { entertains. }\end{array}$ \\
\hline $\begin{array}{l}\text { Do the principles/values/ } \\
\text { reforms remain once the term } \\
\text { has ended? }\end{array}$ & $\begin{array}{l}\text { Does the access to new net- } \\
\text { works remain once the term } \\
\text { has ended? }\end{array}$ & $\begin{array}{l}\text { Does the status remain once } \\
\text { the term has ended? }\end{array}$ \\
\hline
\end{tabular}

vis-à-vis each other. ${ }^{34}$ Recent focus on status includes the proposition that status is the only type of power available to states not qualified for great-power competition. A candidature for a seat in the Security Council has also been suggested as an important expression of smaller states' status seeking. ${ }^{35}$ In a related vein, power as emergent to social interaction is an important point of departure within practice theory. Rebecca Adler-Nissen and Vincent Pouliot demonstrate how states seek and reach influence in multilateral negotiations through tactics to establish skillfulness. Moreover, Jason Ralph and Jess Gifkins show how elected members challenge the dominance of the $\mathrm{P}_{5}$ by proving their competence in the practice of "pen-holding." 36 Translated into the candidature for an elected seat, we may expect states to consider a term in the Council to be relevant as an opportunity to influence the agenda (for example by promoting norms), to establish stronger networks with like-minded states, and to elevate or maintain status.

We divided each of these broader categories into more specified aims, as illustrated in Table 1. These are illustrations of the types of benefits we thought state representatives might express as reasons for seeking a candidature on the Council. For example, a candidate might aim to influence the agenda on a specific issue related to national security, or to promote certain values and principles related to the multilateral order, including efforts toward reform. A candidate might also aim for the opportunity to interact and establish better relationships with the permanent members as well as with other relevant

$34 \quad$ Galtung 1964; Wallace 1971.

35 De Carvalho and Neumann 2015.

$36 \quad$ Adler-Nissen and Pouliot 2014; Ralph and Gifkins 2017. 
actors. Moreover, candidates might expect a term in the Council to result in improved diplomatic competence. Finally, a candidate might aim for the status connected with being an elected member. This might be for the purpose of wanting to elevate one's international role as well as to confirm the status one already holds. We kept open the possibility that the results of the empirical study could generate further insights not captured by this framework.

\section{$4 \quad$ Design and Method}

Our strategy for the empirical investigation was to investigate whether the categories developed in the theoretical section were found in the views and beliefs expressed by diplomats at the permanent missions to the UN in New York. We expected the interviewees to have unique knowledge and insight given their official appointment as diplomats to the $\mathrm{UN}$, and we therefore regarded them as elite informants. While interviews with politicians would have had great value as well, we were mindful of calls for increased focus on diplomats and their views. ${ }^{37}$ Because diplomats are highly skilled in presenting a preferable view of the state they represent, however, we were mindful of biases toward what is socially desirable such as expressing an aim of influencing the agenda in line with widely shared principles as a reason for a candidature. The design of the inquiry gave us some opportunity to critically evaluate the responses in the sense that we were able to compare responses to why their own states sought representation in the Council with their assessments of why other states chose to do so.

During the time period 25 September 2017 to 4 April 2018, we interviewed fifty-three diplomats via telephone and three diplomats in person. The response rate was therefore 27 percent. Nineteen states actively declined to participate, mostly based on state policy not to take part in investigations like this. If these nineteen states are not included in the population, the net response rate is 32 percent. A further thirty-two states responded through email or over the telephone, but were either not able to confirm a date or did not respond at all to follow-up requests to schedule an appointment. The response rate was modest, but still allowed us to explore the benefits of a seat. For studies using this particular method on the European Union level, the response rate is often 
much higher. ${ }^{38}$ This was also a pattern visible in our investigation; states from Europe were overall much more inclined to participate, and twenty-five European states did participate. This means that our conclusions may apply better to European countries than for others. In the Appendix, we provide some additional information regarding the telephone interview survey.

We introduced each theoretical question with an open-ended question; for example, "Why is it of interest to your country to serve as an elected member of the SC [Security Council]?" or "In general, are there more reasons for why states seek an elected seat in the SC?" The next part of the survey was devoted to questions where the countries estimated (on a scale) their influence, their ability to establish relationships, and their status as a result of holding a seat. Each question regarding the scales corresponds to one of the three theoretical models presented in Table 1. Thereafter, we posed open-ended questions that allowed the interviewees to elaborate on their estimations.

The operationalizations were developed beforehand but, once the answers were collected, we added more categories to better capture the detail included in the data. We get back to these new categories in the next section since they might point us in a direction where the theory needs to be refined. Looking at the question "Why is it of interest to your country to serve as an elected member of the SC?" might provide a sense of how we related the theoretical framework to answers given in the interviews. Answers mentioning a will to influence the work or agenda of the Security Council, achieve economic advantages, and get something back from the seat, as well as promoting certain values or principles, relate to the first category in Table 1. Answers mentioning stronger relationships with other actors and the opportunity to gain experience/capacity-building relate to the second category in Table 1 . And finally, answers mentioning status seeking, reputation building, or being recognized are part of the third theoretical model in Table 1. Institutional factors, such as turn-taking or regional rotation schemes, and other factors are not covered by our theoretical framework.

\section{5}

\section{Results: States' Expectations for Power-Enhancing Benefits}

The first set of questions sought to uncover the views and beliefs of diplomats regarding why states seek an elected seat in the Security Council. For countries that since 1990 had campaigned for a seat at least once, we asked the mission

$38 \quad$ Aggestam and Johansson 2017; Johansson 2015. 


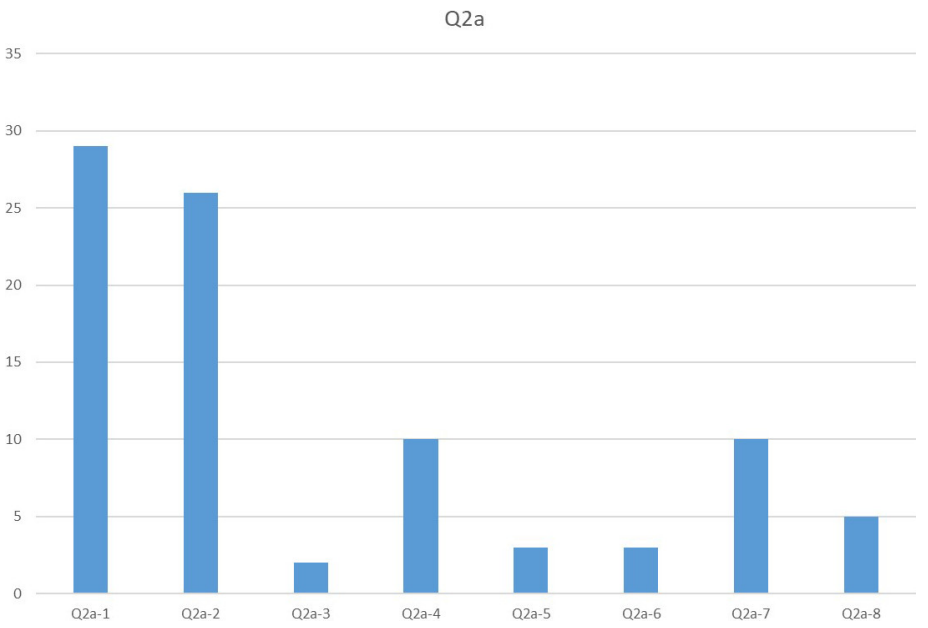

FIGURE 1 Why do states seek a nonpermanent seat in the UN Security Council?

Comment: In your opinion, why is it of interest to your country to serve as an elected member of the SC? Open-ended question. Codes used: 1 . Influence the agenda/work of the UNSC. 2. Take responsibility/sense of obligation to contribute. 3. Stronger relationships with other actors/networking. 4. Status-seeking/reputation/be seen in the international arena. 5. Achieve economic advantages/get something from the money/resources invested in the UN. 6. Opportunity to gain experience for the diplomatic corps/capacity building. 7. Country specific issues/politics (e.g., policy of running at regular intervals). 8. Other.

representatives why it was of interest to their country to serve as an elected member of the Council. The respondents' answers are summarized in Figure 1.

As Figure 1 shows, many reported that a key rationale for seeking a seat was to influence the agenda and work of the Security Council. Often, this was expressed in terms of a wish to shape the work of the Council on matters relating to international peace and security, either in general or in relation to particular conflicts. As one interviewee noted, "Being a member is for [my country] motivated by a desire to contribute on peace, and to influence international public opinion in international peace and security issues." Many diplomats also expressed a wish to influence the work of the Council on particular issues, or a wish to move particular topics (e.g., climate change) onto the agenda. As one respondent noted, "Another reason [is to focus on] new and emerging issues, such as climate change, which has become important and has security implications." Here, a seat in the Council was seen as a means to wield power 
through influence. Almost equally frequent were reasons related to responsibility and obligation. For most states, this was expressed in terms of having a sense of responsibility for contributing to a rules-based multilateral order. As one respondent noted, "Sitting on the SC is a responsibility more than a privilege; acting on behalf of the world." Some diplomats also expressed a sense of responsibility owing to a long-standing relationship with the UN, or as a way of expressing gratitude for UN involvement in local conflicts and development. This factor has been interpreted as if states want to pursue certain values and principles in world politics and that the seat gives them the opportunity to drive the agenda in this particular direction. Among the other factors, status seeking and being seen in the international arena were also reported by a number of countries. Country-specific issues, such as having a policy of running for a seat at regular intervals or domestic politics, were equally frequent. A small number of countries-mainly, major donors and troop contributorsalso expressed that they wanted to get something out of their investment in the UN - this can also be interpreted as an expression of wanting more influence. Perhaps surprisingly, few countries mentioned seeking a seat as a means to enhancing relationships with other actors.

It is interesting to compare these results to the responses given about states' own (expressed) reasons for seeking a seat. In line with the results from the first question, Figure 2 shows that the wish to influence the agenda and the workings of the Security Council was expressed as a central reason for seeking a seat, in general. Reasons related to responsibility as well as obligation were notably less frequent for this question. It is also interesting to note that reasons to do with prestige and status seeking were more frequently mentioned for this question compared with the question asking about the country's own reasons for seeking a seat. Hence, it seems that holding a seat in the Council is seen by many as a symbol of status, or, perhaps more accurately, that many diplomats think other states see it that way. In the words of one respondent, "Some might want to be there for prestige, some for pure cosmetic reasons. It looks good." State-specific reasons, such as having a policy of running at regular intervals (mostly mentioned in the context of major powers with aspirations for a permanent seat) or being a small country (combined with the view that small countries too should have a seat at the table), were also mentioned by some. This applies as well for reasons related to regional rotation schemes. Overall, these answers indicate that many see a seat in the Council as an opportunity to wield influence and that there is a tendency to attach more weight to selfinterest and prestige when it comes to judgments about other states.

The next part of the questionnaire sought to uncover views about influence. We first asked about the extent to which interviewees thought they would be 


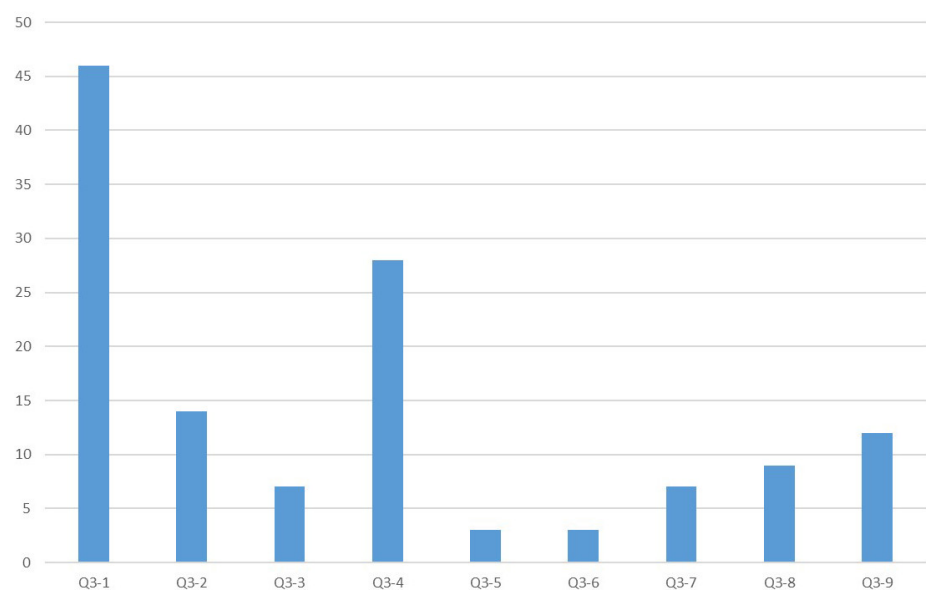

FIGURE 2 What do states think about other states' reasons for seeking a seat in the UN Security Council?

Comment: In general, and not only thinking of your own country, are there more reasons for why states seek an elected seat on the SC? Open-ended answer. Codes used: 1 . Influence the agenda/work of the UNSC. 2 . Take responsibility/sense of obligation to contribute. 3. Stronger relationships with other actors/networking. 4. Status-seeking/reputation/be seen in the international arena. 5. Achieve economic advantages/get something from the money/resources invested in the UN. 6. Opportunity to gain experience for the diplomatic corps/capacity building. 7. Country specific issues/politics (e.g., policy of running at regular intervals). 8 . Reasons related to regional rotation schemes. 9. Other.

able to influence the Security Council agenda if elected. The distribution of the answers is shown in Figure 3.

As Figure 3 shows, a significant majority of the interviewed states gave a medium score (4-6), indicating that while many felt there was some scope of influence, this was limited. This is reflected in the fact that the average score for this question was 5.32. However, many diplomats gave examples of things they had been able to accomplish during previous terms on the Security Council as a way of showing that the scope for influence, while limited, is not necessarily insignificant. When asked to elaborate on their answers (see Figure 4), many expressed the view that their influence would be limited by the role played by the veto powers, and that most of the agenda is already set by the $\mathrm{P}_{5}$ as well as by current events and the renewal of peacekeeping missions and sanctions. However, many diplomats also expressed the view that the scope of influence is greater when it comes to procedural issues and debates (when the veto does 


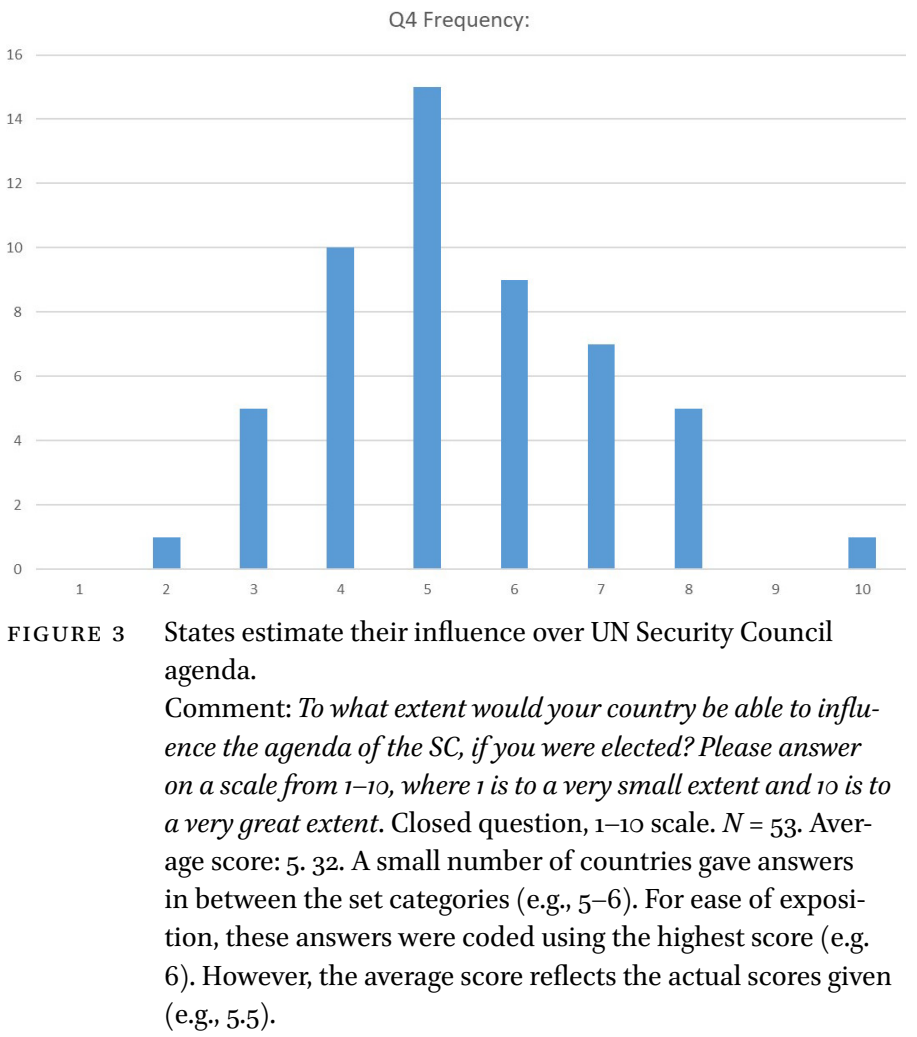

not apply), and for issues where the states' own region is concerned. Moreover, many expressed the view that the scope of influence tends to increase when the state holds the rotating presidency of the Council. Overall, this indicates that many states see a seat as an opportunity to wield influence, even though it does not come with as much power as many would have liked. As one respondent noted, "Given the SC structure, agenda is dominated by the $\mathrm{P}_{5}$. They have the veto, and experience and knowledge of SC processes ... Still, it provides an opportunity to help set the agenda."

We next asked about the extent to which an elected seat would improve the ability to establish stronger relationships with other significant actors in global politics. The distribution of the scores (using the same scale as for the previous question) is shown in Figure 5 .

As Figure 5 shows, countries took a much more positive view here, compared with the question about influence over the agenda. The average score for this question was 7.37. This result indicates that the expected advantages of holding a seat go beyond the ability to influence the agenda of the Security Council, and that many see a seat as a means for networking and power-enhancing 


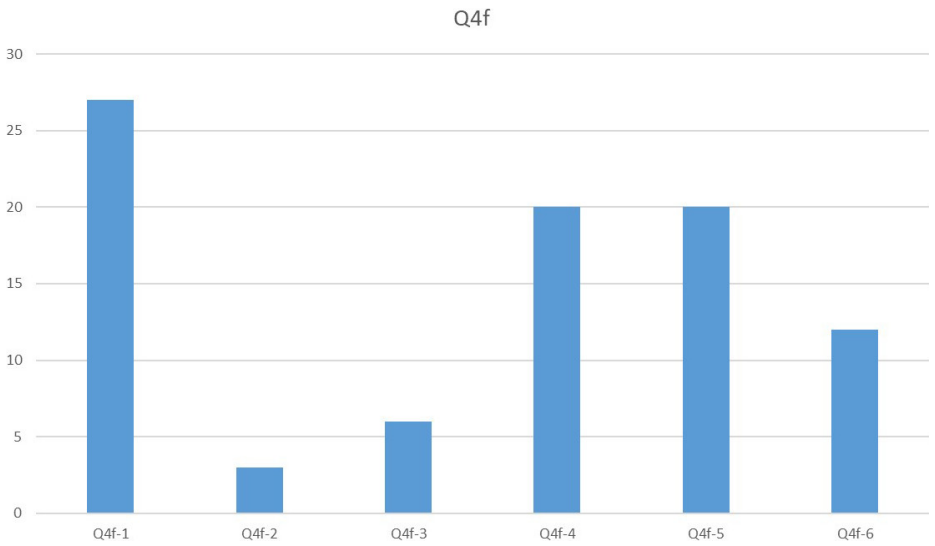

FIGURE 4 States estimate influence over UN Security Council agendaelaborated answers.

Comment: Open-ended question where respondents were asked to elaborate on the score they gave to $Q_{4}$. Codes used: 1. The permanent members decide/are significantly more influential than the NP members. 2. Difficult to build alliances in the SC. 3. We are a small country/have limited resources. 4 . Holding the presidency helps. 5. Influence is issue-specific (e.g., more influence regarding procedural issues and debates; issues relating to own country or region). 6 . Agenda is mostly determined current affairs/circumstances, or automatic/recurring items (e.g., renewal of peacekeeping operations).

social interaction. We also asked the interviewees to elaborate on the score they gave, as seen in Figure 6.

The answers show that three reasons stand out. First, having a seat on the Security Council makes you interesting to others. This was often expressed in terms of the importance of the vote, and in terms of the access to information that the elected members have. As one respondent noted. "You are seen as someone with influence. This attracts attention, and you can become more engaged." Many reported that this makes their country interesting to others, especially for states with a vested interest in conflicts and issues on the Council's agenda. Second, many expressed that the regular contact with the $\mathrm{P}_{5}$ is beneficial, and that the $\mathrm{P}_{5}$ will take a much greater interest in you once you are in the Council. Third, many expressed that holding a seat is also beneficial because it enables contact with countries in other parts of the world that they would not otherwise have had much contact with. This response was particularly frequent for small states with a limited network of embassies and diplomatic missions. Overall, this indicates that many see a seat as a means for networking with other countries. 


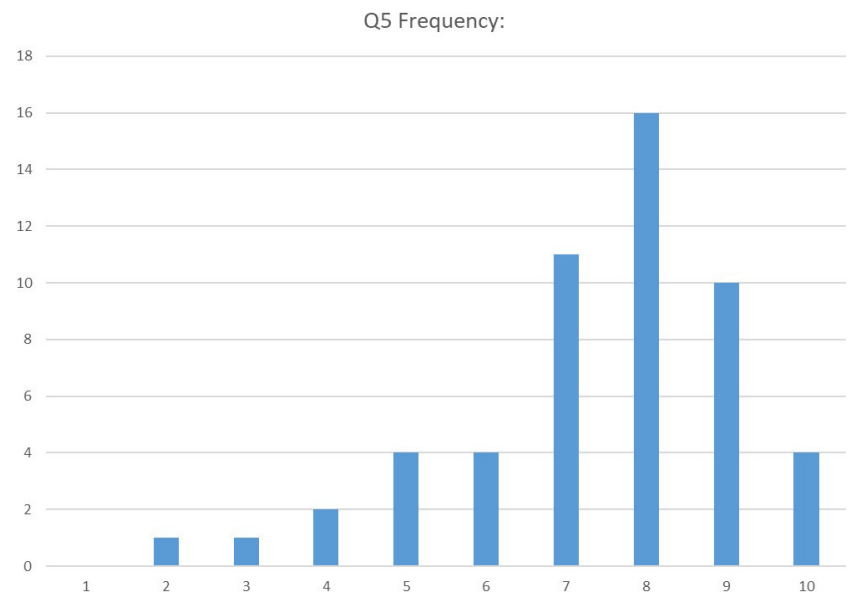

FIGURE 5 States estimate ability to establish stronger relationships with other important actors.

Comment: Would an elected seat improve your country's ability to establish stronger relationships with other significant actors in global politics? Please answer on the scale from 1-10, where 1 is to a very small extent and 10 is a very great extent. Closed question, $1-10$ scale. $N=53$. Average score: 7.37. A small number of countries gave answers in between the set categories (e.g., $5^{-6}$ ). For ease of exposition, these answers were coded using the highest score (e.g., 6). However, the average score reflects the actual scores given (e.g., 5.5).

For the final question relating to influence, we asked whether an elected seat would elevate their country's status in the global community. The distribution of the scores is shown in Figure 7.

As Figure 7 shows, the answers indicate that holding an elected seat is indeed considered beneficial for a state's status. The average score for this question was 6.93. This score ties in well with the conception of power as status seeking mentioned in Table 1. However, the scores were more evenly distributed compared with the question about the effect on ability to establish stronger relationships with others. When we asked the respondents to elaborate, the distribution of answers shown in Figure 8 emerged.

As Figure 8 shows, the most frequent answer was that holding a seat would increase visibility and prominence. However, many also expressed that this is limited to the two years served on the Security Council as well as immediately before and after the term. As one respondent noted, "It is a little bit conditional. Before and during absolutely. After, it is more depending on what you have delivered." Some also expressed the view that the increase in status was 


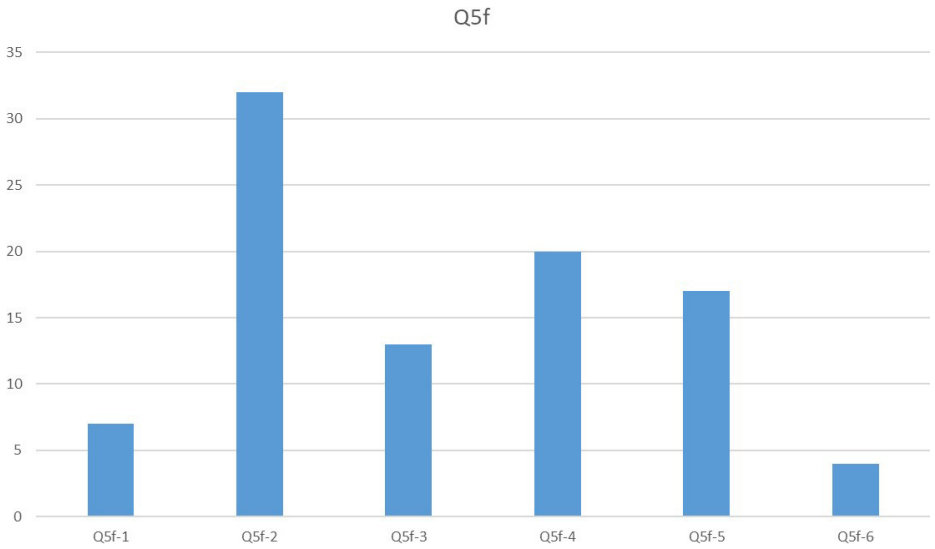

FIGURE 6 States estimate ability to establish stronger relationships with other important actors-elaborated answers.

Comment: Open-ended question where respondents were asked to elaborate on the score they gave to $Q_{5}$. Codes used: 1. Allows you to represent your region. 2. Influence in the SC makes you interesting to others. 3. Provides visibility for country/positions. 4. The close contact with the $\mathrm{P}_{5}$ helps. 5. Enables contact with new countries that you had little contact with before. 6 . Other factors are more important for establishing relationships.

mostly limited to the UN community in New York, and that the impact abroad might not be equally significant. It is also worth mentioning that several countries expressed that the act of campaigning for a seat itself can be a symbol of status. Several diplomats also expressed that other reasons, such as the state's general standing in the world and economic status and power, are more important determinants of its status.

The most interesting findings of the study are reached by comparing: (1) stated reasons for wanting a seat with estimations of the power-enhancing benefits brought by a seat; and (2) reasons ascribed to other states for wanting a seat with the stated reasons for one's own state. When diplomats were asked why a seat was of interest, they rated the opportunity to influence the agenda as the main reason. When asked about the benefits of holding an elected seat, they were modest in their ratings of this type of influence. Conversely, they were optimistic in their assessment on the opportunity to establish networks, but this was not among the most important stated reasons for wanting a seat. 


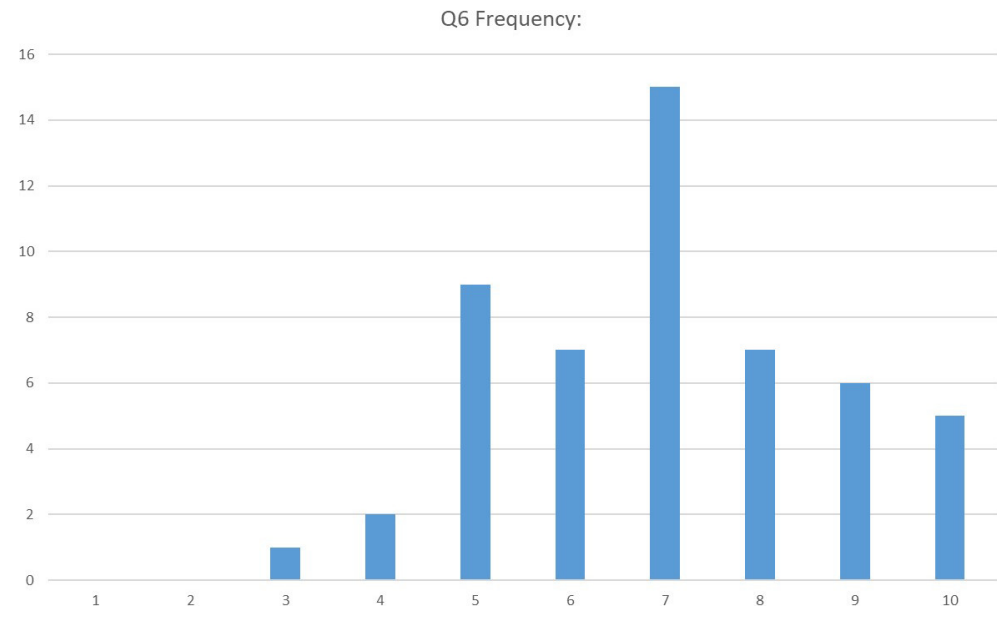

FIGURE 7 States estimate potential for elevated status in the global community.

Comment: Would an elected seat elevate your country's status in the global community? Please answer on the scale from 1-10, where 1 is to a very small extent and 10 is to a very great extent. Closed question, 1-10 scale. $N=5^{2}$. Average score: 6.93 . A small number of countries gave answers in between the set categories (e.g., $5^{-6}$ ). For ease of exposition, these answers were coded using the highest score (e.g., 6 ). However, the average score reflects the actual scores given (e.g., $5 \cdot 5)$.

The pattern for status was similar, although the difference was not as accentuated; status was not a main reason for wanting a seat, but expectations that an elected seat brings status were rather high.

It might seem puzzling that a main reason for wanting a seat was to influence the agenda when assessments of the opportunity to do so were so modest. However, this indicates awareness of the actual obstacles facing the elected members and that influence is still greater with than without a seat. Moreover, it may be that improved relations and status are seen by states as (direct or indirect) forms of influence too, making the discrepancy between influence as a reason for seeking a seat and the reported lack of influence on Security Council decision-making less of a puzzle. Regarding the expectation of stronger relationships with other actors, the results indicate that this was a by-product of the seat and not the main reason for seeking a seat in the first place. The expectation of improved status should be considered in light of the view expressed by many states that any increase in status is temporary and perhaps also limited to UN circles in New York. Hence, the conceptualization of power-enhancing benefits through networking and social interaction helps us understand states' expectations once the seat is won. 


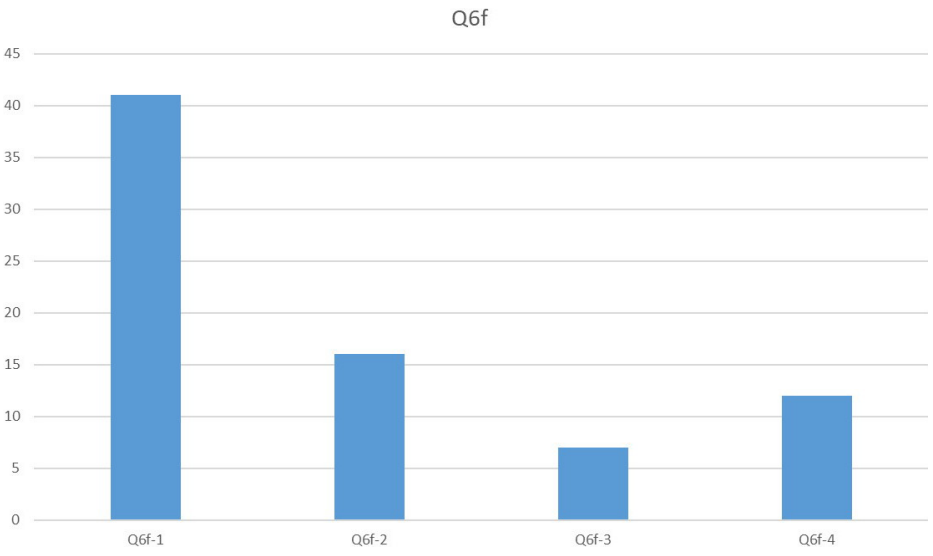

FIGURE 8 States estimate potential for elevated status in global community-elaborated answers.

Comment: Open-ended question where respondents were asked to elaborate on the score they gave to Q6. Codes used: 1. Because it increases visibility and prominence. 2 . Yes, but only temporarily/during or immediately before/after your tenure. 3. Depends on how active you are on the SC/what you achieve. 4 . Other factors are more important for status.

The sense of obligation and ambition to take responsibility for the multilateral order expressed by many diplomats can be interpreted as a will to pursue and promote specific values and norms through the seat. By contrast, when diplomats were asked about other states' reasons for wanting a seat, their will to influence was to a much lesser degree paired with the wish to contribute to the multilateral order, and the aspirations for status were stated as much more important. The difference in responses regarding their own and other states can mean several things. For one, it could be that, when asked about other states, respondents were more honest and that the interest in status in fact applied to their own state as well. On the other hand, it could be that states generalize based on the existence of a few well-known examples of status seekers. Moreover, the tendency to attach less weight to the wish to influence for promoting values and norms and more weight on status seeking of other states might be interpreted as if states perceive a competition over status in these international settings that they do not want to admit. Some states might also connect status seeking with small-state behavior and this might be easier to admit for other states than for their own. In addition, some states might want a seat to preserve a certain status and to remain relevant in global politics, while others seek a seat to improve their status and become more relevant. 
When it comes to the theoretical implications of our study, it is noteworthy that seeing status as a power-enhancing benefit paved the way for an intriguing finding in terms of the discrepancy between stated reasons for one's own state and other states. It points to the relevance of the ongoing move within the literature toward incorporating a social dimension to the understanding of power and influence. The tendency to ascribe collective goals for seeking influence to one's own state, but not to other states, is another finding that points to the remaining relevance on the debate between international relations theories on self-interested and collective purposes for action as well as with regard to the importance of values and norms in world politics.

All three conceptualizations of power-enhancing benefits have proved useful in our analysis, albeit to a varying extent and in different ways. For example, the prevalence on influence as a reason for seeking a seat in the Security Council may be seen to reflect the conceptualization of power that leans toward a material understanding of power consistent with neorealism. On the other hand, the reported emphasis on values and reform seems more in line with the neoliberal view. Finally, the reported presence and relevance of status considerations might be said to reflect more of a social understanding of power in line with the constructivist view.

Previous studies on the candidatures and election of members to the Security Council have only briefly addressed the question of why states seek an elected seat. Indeed, to our knowledge there are no empirical studies focusing specifically on this topic. Our article addresses this gap by focusing on the expectations that states have on an elected seat in the Council. Even with the modest response rate taken into account, it gives a substantial contribution to our understanding of why states run for a seat. Looking ahead, we believe this article opens the way for important future research on states' reasons for international cooperation and interaction, in relation to a seat in the Council as well as in relation to other forms of international representation. It would, for instance, be relevant to investigate how states with different characteristics relate to the three different power-enhancing benefits and by doing so control for some possibly important background variables: Do middle-range powers have greater expectations (than smaller states) on the opportunity to influence the agenda in different institutional settings? Do states with a lower level of international integration have greater expectations regarding the opportunity for social interactions? Do smaller states have greater expectations of status through an elected seat in the Council, or in other international organizations? In addition, structured case comparisons would be beneficial for the purpose of analyzing whether and how the campaigns for international representation reflect the described expectations. Do states with high expectations on influ- 
ence, networking, or status invest more time and money in the campaigns? And are the campaigns designed differently depending on what states hope to achieve through a seat?

\section{Bibliography}

Adler-Nissen, Rebecca, and Vincent Pouliot. "Power in Practice: Negotiating the International Intervention in Libya." European Journal of International Relations 20 (4) (2014), 889-911.

Aggestam, Lisbeth, and Markus Johansson. "The Leadership Paradox in EU Foreign Policy." JCMS: Journal of Common Market Studies 55 (6) (2017), 1203-1220.

Barnett, Michael, and Raymond Duvall. "Power in International Politics." International Organization 59 (1) (2005), 39-75.

Bartelson, Jens. “Three Concepts of Recognition." International Theory 5 (1) (2013), 107129 .

Bueno de Mesquita, Bruce, and Alastair Smith. "The Pernicious Consequences of UN Security Council Membership." Journal of Conflict Resolution 54 (5) (2010), 667-686.

De Carvalho, Benjamin, and Iver B. Neumann. Small State Status Seeking: Norway's Quest for International Standing (London and New York: Routledge, 2015).

Dreher, Axel, Mathew Gould, Matthew D. Rablen, and James Raymond Vreeland. "The Determinants of Election to the United Nations Security Council." Public Choice 158 $(1-2)(2014), 51-83$.

Dreher, Axel, Jan-Egbert Sturm, and James Vreeland. "Does Membership on the UN Security Council Influence IMF Decisions? Evidence from Panel Data." KOF Working Paper No. 151 (Zürich: ETH Zürich, 2006).

Dreher, Axel, Jan-Egbert Sturm, and James Vreeland. "Development Aid and International Politics: Does Membership on the UN Security Council Influence World Bank Decisions?" Journal of Development Economics 88 (1) (2009), 1-18.

Drieskens, Edith. "Curb Your Enthusiasm: Why an EU Perspective on UN Security Council Reform Does Not Imply an EU Seat." Global Affairs 1 (1) (2015), 59-66.

Finnemore, Martha. National Interests in International Society (Ithaca: Cornell University Press, 1996).

Finnemore, Martha, and Kathryn Sikkink. "International Norm Dynamics and Political Change." International Organization $5^{2}$ (4) (1998), 887-917.

Galtung, Johan. "A Structural Theory of Aggression." Journal of Peace Research 1 (2) (1964), 95-119.

Gregg, Robert W. “The Latin American Bloc in United Nations Elections.” Southwestern Social Science Quarterly 46 (2) (1965), 146-154.

Honneth, Axel. The Struggle for Recognition: The Moral Grammar of Social Conflicts (Oxford: Polity Press, 1995). 
Hurd, Ian. After Anarchy: Legitimacy and Power in the United Nations Security Council (Princeton: Princeton University Press, 2008a).

Hurd, Ian. "Legitimacy, Power, and the Symbolic Life of the UN Security Council." Global Governance 8 (1) (2008b), 35-51.

Hurd, Ian. "Myths of Membership: The Politics of Legitimation in UN Security Council Reform." Global Governance 14 (2) (2008c), 199-217.

Johansson, Markus. Negotiations as Usual: Putting Domestic Constraints on the Table in the Council of the European Union. PhD Thesis (University of Gothenburg, Department of Political Science, 2015).

Keating, Colin. "Power Dynamics between Permanent and Elected Members." In von The UN Security Council in the 21st Century, eds. Sebastian von Einsiedel, David M. Malone, and Bruno Stagno Ugarte (Boulder: Lynne Rienner, 2016).

Keohane, Robert O., and Joseph S. Nye Jr. "Power and Interdependence in the Information Age." Foreign Affairs 77 (5) (1998), 81-94.

Kuziemko, Ilyana, and Eric Werker. "How Much Is a Seat on the Security Council Worth? Foreign Aid and Bribery at the United Nations." Journal of Political Economy 114 (5) (2006), 905-930.

Langmore, John, and Jeremy Farrall. "Can Elected Members Make a Difference in the Security Council? Australia's Experience in 2013-2014." Global Governance 22 (1) (2016), 59-77.

Lebow, Ned R. Cultural Theory of International Relations (Cambridge: Cambridge University Press, 2008).

Luck, Edward C. UNSecurity Council: Practice and Promise (New York: Routledge, 2006). Malone, David. "Eyes on the Prize: The Quest for Nonpermanent Seats on the UN Security Council." Global Governance 6 (1) (2000), 3-23.

Mearsheimer, John J. The Tragedy of Great Power Politics (New York: Norton, 2001).

Nye, Joseph S., Jr. Power in the Global Information Age: From Realism to Globalization (London: Routledge, 2004).

Paul, T.V., Deborah Welch Larson, and William Wohlforth, eds. Status in World Politics (New York; Cambridge University Press, 2014).

Pettit, Philip. A Theory of Freedom: From the Psychology to the Politics of Agency (New York: Oxford University Press, 2001).

Ralph, Jason, and Jess Gifkins. "The Purpose of United Nations Security Council Practice: Contesting Competence Claims in the Normative Context Created by the Responsibility to Protect." European Journal of International Relations 23 (3) (2016), $630-653$.

Ringmar, Erik. Identity, Interest and Action: A Cultural Explanation of Sweden's Intervention in the Thirty Years War (New York: Cambridge University Press, 1996).

Ringmar, Erik. "The Recognition Game: Soviet Russia against the West." Cooperation and Conflict 37 (2) (2002), 115-136. 
Sharp, Paul. "For Diplomacy: Representation and the Study of International Relations." International Studies Review 1 (1) (1999), 33-57.

Sievers, Loraine, and Sam Daws, The Procedure of the UN Security Council. 4th ed. (Oxford: Oxford University Press, 2014).

Singer, Marshall R., and Barton Sensenig. "Elections within the United Nations: An Experimental Study Utilizing Statistical Analysis." International Organization 17 (4) (1963), 901-925.

Thakur, Ramesh. "United Nations Security Council Reform.” African Security Review 13 (3) (2004), 66-74.

Vreeland, James, and Axel Dreher. The Political Economy of the United Nations Security Council: Money and Influence (New York: Cambridge University Press, 2014).

Wallace, Michael D. "Power, Status and International War." Journal of Peace Research 8 (1) (1971) 23-35.

Waltz, Kenneth N. Theory of International Politics (Long Grove: Waveland Press, 2010). Weigert, Kathleen Maas, and Robert E. Riggs. "Africa and United Nations Elections: An Aggregate Data Analysis." International Organization 23 (1) (1969), 1-19.

Wendt, Alexander. "The State as Person in International Theory." Review of International Studies 30 (2) (2004), 289-316.

Wolf, Reinhard. "Respect and Disrespect in International Politics: The Significance of Status Recognition." International Theory 3 (1) (2011), 105-142. 


\section{Appendix}

All 193 UN Member States were contacted with a request to take part in a telephone interview. Requests were sent out via email to addresses collected via the official home pages of the permanent mission to the UN in New York, and/or through Google searches and UN directories. Interview requests were sent out in several waves, and the countries that did not respond to earlier requests were contacted around five to six times.

In total, fifty-six interviews were completed. Nineteen countries explicitly denied the request for an interview, either as a result of state policy or due to a busy schedule.

The distribution of the respondents according to category is as follows:
1. Ambassador/Permanent Representative 33
2. Other higher diplomatic position 20
3. Other mission representative 